\begin{tabular}{|l|l|l||}
\hline \multicolumn{2}{|c|}{ PublisherInfo } \\
\hline \hline PublisherName & $:$ & BioMed Central \\
\hline \hline PublisherLocation & $:$ & London \\
\hline \hline PublisherImprintName & $:$ & BioMed Central \\
\hline \hline
\end{tabular}

\title{
Integrated chromosomal maps
}

\begin{tabular}{|c|c|}
\hline \multicolumn{2}{|c|}{ ArticleInfo } \\
\hline ArticleID & 3612 \\
\hline ArticleDOI & 10.1186/gb-2000-1-1-reports238 \\
\hline ArticleCitationID & reports 238 \\
\hline ArticleSequenceNumber & 103 \\
\hline ArticleCategory & Web report \\
\hline ArticleFirstPage & 1 \\
\hline ArticleLastPage & 4 \\
\hline ArticleHistory & $\begin{array}{ll}\text { RegistrationDate } & : 2000-1-28 \\
\text { Received } & : 2000-1-28 \\
\text { OnlineDate } & : 2000-4-27\end{array}$ \\
\hline ArticleCopyright & BioMed Central Ltd2000 \\
\hline ArticleGrants & \\
\hline ArticleContext & 130591111 \\
\hline
\end{tabular}




\section{Abstract}

The unified database (UDB) attempts to create an integrated map based on human genome mapping data retrieved from a number of public databases.

\section{Content}

The unified database (UDB) attempts to create an integrated map based on human genome mapping data retrieved from a number of public databases. The maps place sequence-tagged sites (STSs) and expressed sequence tags (ESTs) from a number of sources on each chromosome at kilobase resolution, the scale being primarily based on a conversion of centi-rays $(\mathrm{cR})$ to megabases $(\mathrm{Mb})$, where a $\mathrm{cR}$ is a radiation breakage unit that is approximately equal to a one percent chance of a break between two markers. Three different types of map have been integrated in a hierarchical fashion: radiation hybrid (RH); genetic; and yeast artificial chromosome (YAC) STS content maps.

\section{Navigation}

Searching the database is very straightforward and the search options are comprehensive. The initial search is by chromosome number and the search area is then narrowed by specification of cytogenetic band, position (in $\mathrm{Mb}$ ) or marker interval. It is also possible to search UDB by gene or marker name; this gives the estimated location of the gene as well as links to GeneCards and The Genome Database (GDB). The estimated location was not given for the gene I tried however, despite this being available from both GeneCards and GDB. Finally, you can view the estimated boundaries (in Mb) of the cytogenetic bands of any chromosome.

\section{Reporter's comments}

\section{Timeliness}


The site was updated on 12 January 2000.

\section{Best feature}

This site is a good starting point for anyone constructing a physical or transcript map of a genomic region. It obviates the need to look at a number of different websites and integrate the markers from the different maps.

\section{Worst feature}

The marker order has been determined by integrating the different maps on a hierarchical system. If a marker is on an RH map, that position is used; if not, then the genetic position, if applicable, is converted into a $\mathrm{cR}$ position. If neither of these options is available, the position of the marker on a YAC is used to integrate it with its neighbors, with an equal distance assumed between STSs and a double distance assumed between STSs either side of a gap in the contig. This hierarchical system was presumably used to avoid the inevitable discordances between different maps. But this is not necessarily the best order for integration; in some cases, for example, YAC STS content data may be more accurate than RH data. An algorithm that looked at a variety of different data sources and reached a consensus, while flagging up unresolvable discrepancies, would give a more accurate, if more complicated, result.

\section{Wish list}

The limitations of order and distance (the fact that the relationship between $\mathrm{cR}$ and physical distance is not uniform, and markers are not necessarily evenly spaced in YAC clones) should be pointed out. It would also be useful if there was a link from the STS to the YAC data, where available.

\section{Related websites}

The data used to generate the maps are available from the Whitehead Institute/MIT Center for Genome Research's STS-based map of the human genome, GeneMap'98, Stanford Human Genome Center's RH mapping index and Genethon - Human Genome Research Centre's FTP site.

\section{Table of links}


Unified database for human genome mapping

GeneCards

The Genome Database

STS-based map of the human genome

GeneMap'98

RH mapping index

Genethon - Human Genome Research Centre's FTP site

\section{References}

1. Unified database for human genome mapping. 